\title{
BUILDING A WORK CULTURE IN EFFORTS TO IMPROVE EMPLOYEE PERFORMANCE PT. X
}

\author{
Jihaan Anisa ${ }^{1}$ \\ Eviatiwi Kusumaningtyas Sugiyanto ${ }^{2 *}$
}

Universitas Semarang

Accepted: August 2020, Approved: September 2020, Published: October 2020

\begin{abstract}
This study aims to determine work culture in an effort to improve employee performance at PT X. This research is a qualitative research with a case study approach. Collecting data in this study using triangulation of data sources, namely observation, interviews, and documentation. Six informants were selected based on the principle of suitability(appropriateness) and sufficiency (adequacy).The results showed that PT X's work culture had benefits, namely the formation of a good work process, a more structured job, a faster problem-solving process and increased human resource capabilities. while the barriers in work culture are a lack of confidence, busy daily routines, inefficient organizational structure, lack of motivation and competence, lack of cohesiveness and employees who do not upgrade their abilities or knowledge.
\end{abstract}

Keywords: Employee Work Culture, Employee Performance.

1]Jihan.anisa24@yahoo.co.id; Universitas Semarang

2*eviatiwisugiyanto@usm.ac.id; Universitas Semarang, Correspondent Author 


\section{INTRODUCTION}

Work culture is a system of values, perceptions, behaviors and beliefs held by each individual employee and group of employees regarding the meaning of work and their reflections in achieving organizational and individual goals. It is important to develop a work culture because of its positive impact on achievingchange sustainablein the workplace, including increasing productivity (performance). Performance is the result of work achieved by an employee in carrying out the duties assigned to him. In general, performance is the work performance produced by employees in accordance with the roles and tasks they perform in the agency. Performance is an action or task implementation that can be measured in general performance measures including: quality of work, quantity of work, knowledge of work, and work planning (Sutisna, 2012). Employee performance is important for every organization to pay attention to because humans, in this case employees, are the main factor in the work process which in turn will make the overall performance of the institution run well or not. Increased employee work performance will bring progress for the company to survive in an unstable business environment.

Someone at work does not only want a salary or wage, but they also want inner satisfaction at work, in order to boost the quality of their performance. The problem of work quality and employee performance is a very important matter for the company, because it can be seen to what extent they are motivated to achieve in the framework of company goals. For companies, employee performance is expected to always increase, because employee performance shows a link between work performance and the time it takes to produce goods or services from a workforce. Good employee performance shapes the welfare of life and encourages a system that shapes the availability of human resources for the company, and operational activities to strengthen bargaining power against consumers so that the company can continue to maintain its profitability.

Each function or work process must have a difference in the way of working which results in different values taken in the organizational framework. It is like what values should be owned, how the behavior of each person will affect their work, then the philosophy they adhere to. A long process that is continuously refined in accordance with the demands and capabilities of human resources itself in accordance with recognized guiding principles (Triguno, 2004). The work culture program will become a reality through a long process, because changing old values into new values will take time to 
become a habit and constantly make improvements and improvements.

To build a work culture that can improve employee performance, the leadership of PT. X performs bothcommunication activities internal and external in order to maintain its existence. At first, there were many choices, such as providing coaching to employees, apparently it was not enough for employees. Finally, PT. X applies programs to arouse employee morale, such as: 1). Provide annual leave to employees, 2). give rewards to employees for good cooperation, 3). hold training / seminars, 4). spend vacation time with employees. However, these efforts are still not optimal. This can be seen from the results of employee work reports:

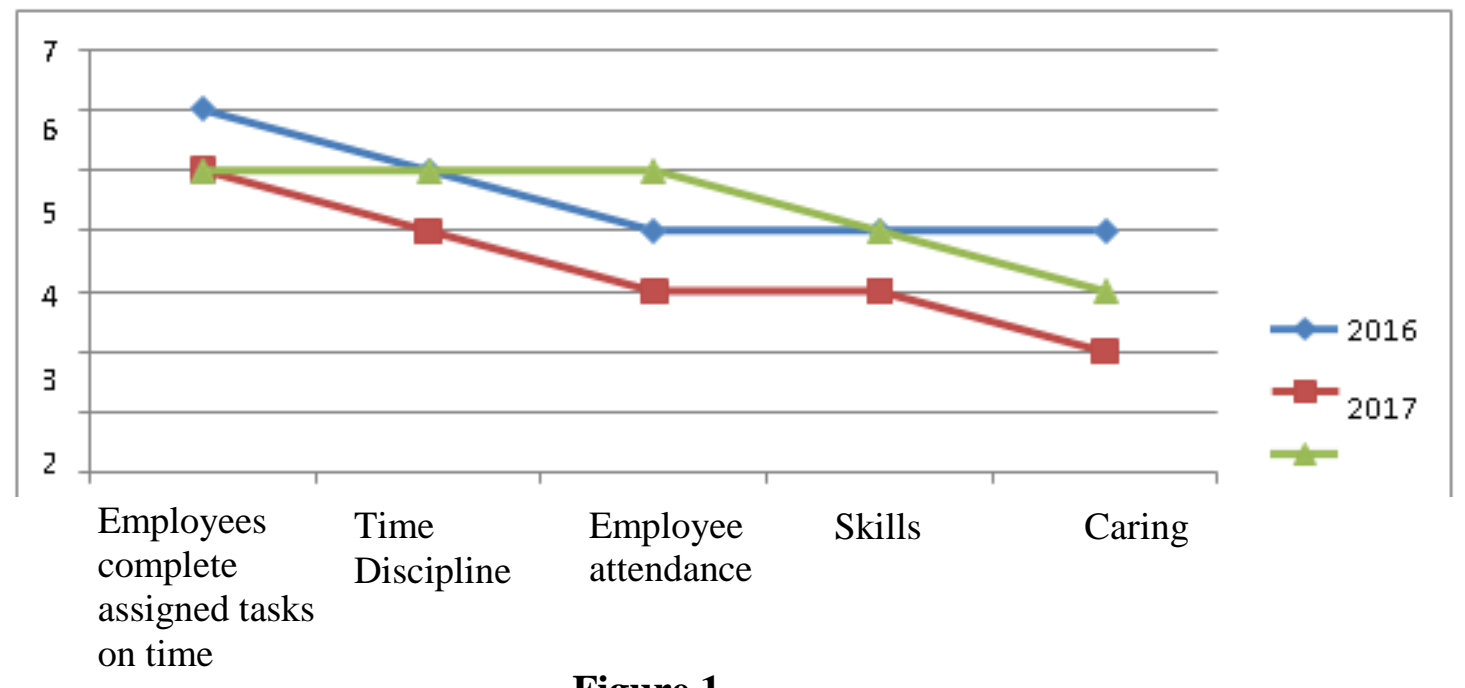

Figure 1

Employee Job Assessment of PT. X

\section{THEORETICAL BACKGROUND}

Work culture is a habit that is repeated by employees in an organization. Violation of this habit does not have strict sanctions, but from the morally agreed organizational behavior that these habits are habits that must be adhered to in the context of carrying out work to achieve goals. Based on the theory above work culture, that is a habit or behavior that is carried out repeatedly in every routine and there are no strict sanctions for breaking it, but habits here are meant as positive habits. Habits are a combination of attitudes and behaviors which have dimensions to be used as a benchmark in attitude and behavior (Nawawi, 2005). Culture as a common pattern of assumptions learned by certain groups to overcome problems of external adaptation and internal integration. Culture is a whole of behavior patterns seen in social life, art, religion, institutions, and all the work and 
thoughts of a human group (Schein, 2010). Five factors influence work culture, namely employee responsibility, innovation, results orientation, knowledge and work systems. These factors will directly affect the work culture of employees in a company or organization.

\section{METHOD, DATA AND ANALYSIS}

This type of research is qualitative research with a case study approach. The case study approach method is used to obtain in-depth data with data that contains meaning. Case study method research is a type of research that describes or reveals a situation so that the indicators of the variables studied can be identified, in order to obtain broader benefits in this study. Besides, everything that is gathered is likely to be the key to what has been researched. Retrieval of informants in this study based on the principles of proficiency and appropriateness. The key informants in this study were 6 people. The results of this study only describe or construct in-depth interviews with research subjects so that they can provide a clear picture of how the company improves the performance of its employees. While the stages in this research can be seen in Figure 2.

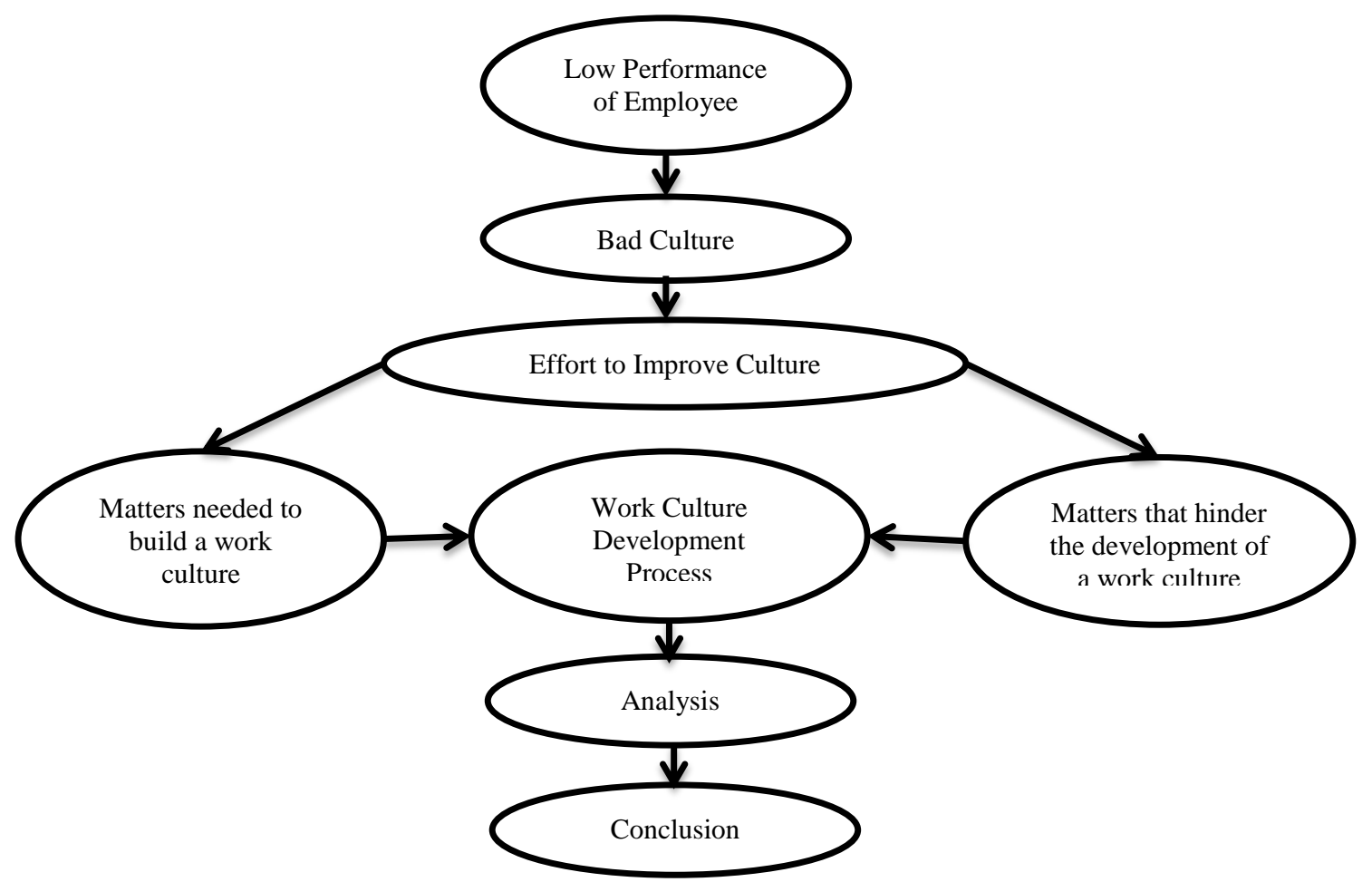

Figure 2

\section{Research Stage}




\section{RESULTS AND DISCUSSION}

Employee performance is the contribution made by employees to the company that can be identified from the work of the employees. The performance of individual employees is a factor that influences the success of a company. Employee work culture can certainly affect employee performance. Having motivation in an employee will encourage the employee to do the job as well as possible. Thus, every individual involved in it will jointly strive to create ideal working conditions in order to create a supportive atmosphere for efforts to achieve the expected goals.

Employee work culture cannot be carried out continuously according to the needs of its development if there are no ties that ensure all employees and management are obedient and obedient to carry it out. So we need a statement from each employee and the ranks of leadership in fulfilling all the conditions outlined. Based on this research, it can be concluded that the higher the work culture of the employees, the higher the employee's performance.

To build a work culture that can improve employee performance, the leadership of PT. X performs both communication activities internal and external in order to maintain its existence. At first, there were many choices, such as providing coaching to employees, apparently it was not enough for employees. Finally, PT. X implements programs to arouse employee morale such as: 1) Providing annual leave to employees, 2) Giving rewards to employees for good cooperation, 3) Conducting training / seminars, 4) Spending vacation time with employees.

\section{CONCLUSIONS}

Based on the results of the analysis conducted by researchers, it can be concluded that there are several ways to build a work culture for employees in the Company, which are as follows:

1. Things that are needed in the Work Culture of PT. X

a) Unite the vision and mission so that employees are even more active at work.

b) The development of companies programs that make employees independent, grow, and thrive.

c) Provide training, direction, assignments, and see what potentials can be developed 
in the company. Provide standardization of work so that they can work more efficiently.

\section{The Benefits of a Good Work Culture at PT. X}

In a company, a reference is needed so that employees can be optimally empowered. These standard references can be manifested in the form of a corporate culture that systematically guides employees to build a company work culture and ultimately improve company performance. Thus the corporate culture plays a strategic function in the operations of a company, including:

a) The formation of employee work processes properly

b) More structured work

c) Speed up the problem-solving process

d) Improve HR Capabilities

3. Inhibiting Factors for the Work Culture of PT. X

Inhibiting factors are important things for evaluation in a company. Inhibiting factors found in PT. $\mathrm{X}$ are:

a) Lack of confidence

b) Employees busy with daily routines

c) Less efficient work structure

d) Employees do not have motivation and competence

e) Lack of cohesiveness between employees \& leaders

f) Employees who do not upgrade skills

\section{IMPLICATIONS}

The implications of this study to PT X, are as follows:

1. Must be sure of what the company has determined for the good of its employees. If the leadership wants the decision to be implemented immediately

2. Focus on the work that has been given the leader. So that the results of employee performance are satisfactory, it would be nice if each employee focuses on their respective jobs in accordance with the jobdesk that has been determined by the company.

3. With a work structure that has been formed by a leader, an employee must comply with the existing regulations in the company. 
4. As a good employee, you must have self-confidence. To obtain this high selfconfidence, a person must have sufficient knowledge, insight, and skills so that the association is broad.

5. A leader should have a high commitment to make decisions about the goals and direction of the company.

6. To make a company progress, employees must be able to keep up with the changing times so as not to be left behind. Improve their knowledge, skill and ability to adapt the changing of the era.

\section{REFERENCES}

Budi, Setiyawan dan Waridin. 2006. Budaya Kerja Karyawan dan Budaya Organisasi Terhadap Kinerja di Divisi Radiologi RSUP Dokter Kariadi, Semarang: JRBI. Vol 2. No 2. Hal: 181-198

Guritno, Bambang dan Waridin. 2005. Pengaruh Budaya Kerja Karyawan Mengenai Perilaku Kepemimpinan, Kepuasan Kerja dan Motivasi Terhadap Kinerja. JRBI.Vol 1. No 1. Hal: 63-74.

Hakim, Abdul. 2006. Pengaruh Motivasi, Komitmen Organisasi Dan Iklim Organisasi Terhadap Kinerja Pegawai Pada Dinas Perhubungan Dan Telekomunikasi Provinsi Jawa Tengah. JRBI.Vol 2. No 2. Hal: 165- 180.

Handoko, T. Hani. 2003. Manajemen Edisi 2. Yogyakarta: BPFE UGM.

Hasibuan, Malayu. 2004. Manajemen Sumber Daya Manusia. Jakarta: Bumi Aksara.

Mangkunegara, Anwar Prabu. 2005. Evaluasi Kinerja SDM, Cetakan Kedua Bandung: Rafika Aditama.

Malthis, R.L dan Jackson. 2001. Manajemen Sumber Daya Manusia. Jakarta: Salemba Empat

Masrukhin dan Waridin. 2004. Pengaruh Motivasi Kerja, Kepuasan Kerja, Budaya Organisasi Dan Kepemimpinan Terhadap Kinerja Pegawai. EKOBIS.Vol 7. No 2. Hal: 197-209

Nawawi, Hadari. 2005. Manajemen Sumberdaya Manusia Untuk Bisnis Yang Kompetitif. Yogyakarta: Gajah Mada University Press.

Rivai, dan Basri. 2005. Manajemen Sumber Daya Manusia Untuk Perusahaan, Jakarta: Rajagrafindo Persada

Schein, Edgar H. 2010. Organizational Culture and Leadership. Fourth Edition.JosseyBass. A Wiley Imprint, Market Street. San Fransisco CA

Siagian, Sondang. P. 2002. Kiat Meningkatkan Produktivitas Kerja. Jakarta: Rineka Cipta. Simamora,

Henry, 2006. Manajemen Sumber Daya Manusia. Yogyakarta: STIE YKPN.

Suwati, Yuli. 2013. Pengaruh Kompensasi Dan Motivasi Kerja Terhadap Kinerja Karyawan Pada PT Tunas Hijau Samarinda. Jurnal Ilmu Administrasi Bisnis. Vol.1. No.1

Tika, P, 2006, Budaya Organisasi Dan Peningkatan Kinerja Perusahaan. Penerbit Bumi Aksara, Jakarta. 